\title{
CRITERIA FOR ABNORMALITY EVALUATION OF SELECTED WEATHER PARAMETERS IN THE SLOVAK REPUBLIC
}

\author{
MARTIN DANILOVIČ ${ }^{*}$, HELENA HLAVATÁ ${ }^{2}$, BOŽENA ŠOLTYSOVÁ ${ }^{1}$ \\ ${ }^{1}$ National Agricultural and Food Centre - Research Institute of Agroecology, Michalovce, \\ Slovak republic \\ ${ }^{2}$ Slovak Hydrometeorological Institute, Košice, Slovak republic
}

DANILOVIČ, M. - HLAVATÁ, H. - ŠOLTYSOVÁ, B.: Criteria for abnormality evaluation of selected weather parameters in the Slovak Republic. Agriculture (Pol'nohospodárstvo), vol. 63, 2017, no. 2, p. 86-91.

\begin{abstract}
The paper describes the procedure of calculation and assessment of deviations of the average air temperature from the normal (in relation to the normal 1961-1990) or long-term average and the percentage of normal precipitation or long-term sum of precipitation, valid for the Slovak Republic. Three evaluation tables clearly indicate both threshold limit values, which facilitate the classification of the calculated indices for air temperature and precipitation. Criteria presented in this work are fully applicable for weather conditions evaluation during the growing season of cultivated plants in the Slovak Republic.
\end{abstract}

Key words: air temperature, precipitation, normality, evaluation worksheet, evaluative criteria

Evaluation of weather conditions during the growing season of cultivated plants, during the year or during the various months of the year has been an essential part of research papers, students' theses, scientific and technical works, projects, vegetation tests and creation of growth models. The most commonly measured weather parameters are air temperature and precipitation, and they are frequently evaluated at many kinds of scientific and technical works, especially in agricultural and natural sciences.

Climate data are more useful when they are compared with normal values (WMO 2007). Climate normals, as discussed by the World Meteorological Organization, are not only used as predictors of future climate conditions, but are also used to provide a reference value for the computation of climate anomalies. A climatological normal is defined as the arithmetic average of a climate element (e.g., temperature) over a 30 -year period. The current climate normal period is calculated from $1^{\text {st }}$ January 1961 to $31^{\text {st }}$ December 1990 and will be used until 2020 (WMO 1989). Climate normals valid for the territory of Slovakia are calculated and published by the Slovak Hydrometeorological Institute (Mikulová et al. $2015 \mathrm{a}, \mathrm{b})$.

Calculated deviation from a normal value was the simplest way to express the relationship between observed and normal conditions and is widely used to detect climate changes. In meteorology, it is a very common way to approach drought or warmth situation by generating an index using meteorological data. These indices can be calculated for a variety of time scales. Usually, these time scales range from a single month to a group of months. For climate data comparison with the normal values, it is necessary

Ing. Martin Danilovič, PhD. (*Corresponding author), Ing. Božena Šoltysová, PhD., National Agricultural and Food Centre - Research Institute of Agroecology Michalovce, Špitálska 1273, 07101 Michalovce, Slovak republic. E-mail: danilovic@ minet.sk

Ing. Helena Hlavatá, PhD., Slovak Hydrometeorological Institute, Regional branch Košice, Ďumbierska 26, 04001 Košice, Slovak Republic. E-mail: Helena.Hlavata@shmu.sk 
to process them using evaluative criteria calculated for the observed territory. There are some differences within the processing data of air temperature and data of precipitation. The aim of this work is to make the evaluation criteria available and provide missing guidance for air temperature and precipitation data processing during the growing season of the cultivated plants in Slovak republic, in relation to the climate normal 1961-1990.

\section{Air temperature}

In cases when concurrent values of monthly or annual air temperature average are compared with normal, the difference tends to be constant (index). Deviation from a normal value is calculated as a difference between the valuated average air temperature and normal for identical period (e.g., month, year). The index is calculated as:

Class limits $\left[{ }^{\circ} \mathrm{C}\right]$ for evaluating the air temperature abnormality of months, years, half years and winter months in the Slovak Republic

\begin{tabular}{|c|c|c|c|c|c|c|c|}
\hline \multirow{4}{*}{$\begin{array}{l}\text { Month / } \\
\text { period }\end{array}$} & \multicolumn{7}{|c|}{ Normal } \\
\hline & 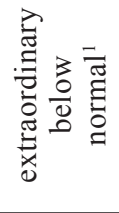 & 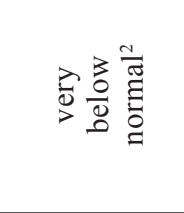 & 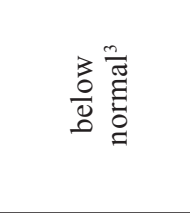 & 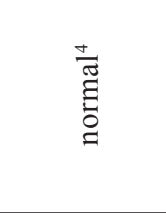 & 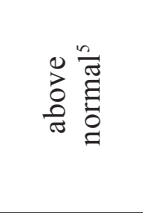 & 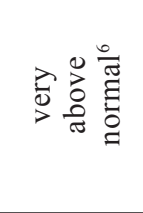 & 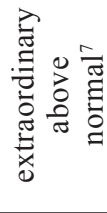 \\
\hline & \multicolumn{7}{|c|}{ Long-term average } \\
\hline & 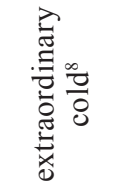 & $\begin{array}{l}\frac{0}{0} \\
8 \\
\frac{0}{0} \\
>\end{array}$ & $\frac{\circ}{0}$ & 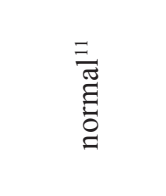 & $\begin{array}{l}\frac{\pi}{E} \\
\frac{\pi}{3} \\
3\end{array}$ & $\begin{array}{l}m^{2} \\
\Xi \\
\bar{E} \\
3 \\
3 \\
0 \\
0\end{array}$ & 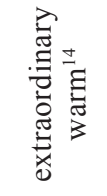 \\
\hline I. & $<-6.5$ & -6.5 to -4.1 & -4.0 to -2.1 & -2.0 to 2.0 & 2.1 to 3.5 & 3.6 to 5.0 & $>5.0$ \\
\hline II. & $<-7.0$ & -7.0 to -4.1 & -4.0 to -1.6 & -1.5 to 2.0 & 2.1 to 3.0 & 3.1 to 5.0 & $>5.0$ \\
\hline III. & $<-5.0$ & -5.0 to -3.6 & -3.5 to -2.1 & -2.0 to 1.5 & 1.6 to 3.0 & 3.1 to 4.5 & $>4.5$ \\
\hline IV. & $<-4.0$ & -4.0 to -2.6 & -2.5 to -1.1 & -1.0 to 1.0 & 1.1 to 2.5 & 2.6 to 4.0 & $>4.0$ \\
\hline V. & $<-3.0$ & -3.0 to -2.1 & -2.0 to -1.6 & -1.5 to 1.5 & 1.6 to 2.5 & 2.6 to 3.5 & $>3.5$ \\
\hline VI. & $<-2.5$ & -2.5 to -1.6 & -1.5 to -1.1 & -1.0 to 1.0 & 1.1 to 2.0 & 2.1 to 3.0 & $>3.0$ \\
\hline VII. & $<-2.0$ & -2.0 to -1.6 & -1.5 to -1.1 & -1.0 to 1.0 & 1.1 to 1.5 & 1.6 to 2.5 & $>2.5$ \\
\hline VIII. & $<-2.5$ & -2.5 to -1.6 & -1.5 to -1.1 & -1.0 to 1.0 & 1.1 to 1.5 & 1.6 to 2.5 & $>2.5$ \\
\hline IX. & $<-3.0$ & -3.0 to -2.1 & -2.0 to -1.1 & -1.0 to 1.0 & 1.1 to 2.0 & 2.1 to 3.5 & $>3.5$ \\
\hline $\mathrm{X}$. & $<-3.5$ & -3.5 to -2.1 & -2.0 to -1.1 & -1.0 to 1.0 & 1.1 to 2.0 & 2.1 to 3.5 & $>3.5$ \\
\hline XI. & $<-4.0$ & -4.0 to -2.1 & -2.0 to -1.1 & -1.0 to 1.0 & 1.1 to 2.0 & 2.1 to 3.5 & $>3.5$ \\
\hline XII. & $<-5.5$ & -5.5 to -3.1 & -3.0 to -1.6 & -1.5 to 1.5 & 1.6 to 3.0 & 3.1 to 4.5 & $>4.5$ \\
\hline I.-XII. & $<-1.5$ & -1.5 to -1.1 & -1.0 to -0.6 & -0.5 to 0.5 & 0.6 to 1.0 & 1.1 to 1.5 & $>1.5$ \\
\hline IV.-IX. & $<-1.5$ & -1.5 to -1.1 & -1.0 to -0.6 & -0.5 to 0.5 & 0.6 to 1.0 & 1.1 to 1.5 & $>1.5$ \\
\hline X.-III. & $<-3.5$ & -3.5 to -2.1 & -2.0 to -1.1 & -1.0 to 1.0 & 1.1 to 1.5 & 1.6 to 2.5 & $>2.5$ \\
\hline XII.-II. & $<-5.0$ & -5.0 to -3.1 & -3.0 to -1.1 & -1.0 to 1.5 & 1.6 to 2.0 & 2.1 to 3.0 & $>3.0$ \\
\hline
\end{tabular}

IV.-IX. - warm half-year; X.-III. - cold half-year; XII.-II. - winter;

Note that in Slovak language we never use term 'extrémne' and classes translate as: ${ }^{1}$ mimoriadne podnormálny, ${ }^{2}$ silne podnormálny, ${ }^{3}$ podnormálny, ${ }^{4}$ normálny, ${ }^{5}$ nadnormálny, ${ }^{6}$ silne nadnormálny, ${ }^{7}$ mimoriadne nadnormálny, ${ }^{8}$ mimoriadne studený, ${ }^{9}$ vel'mi studený, ${ }^{10}$ studený, ${ }^{11}$ normálny, ${ }^{12}$ teplý, ${ }^{13}$ vel'mi teplý,,${ }^{14}$ mimoriadne teplý 


$$
T-n(T)
$$

where:

$\mathrm{T}$ denotes the longer period's average air temperature, $n(T)$ is air temperature normal for the same period and valid for the evaluated site of Slovak Republic (Lapin et al. 1987).

Class limits for the calculated temperature difference categories are presented in the evaluation worksheet (Table 1). Presented class limits were elaborated following the methodology of Slovak
Hydrometeorological Institute (Lapin et al. 1987) and are valid for the territory of Slovakia in relation to the normal 1961-1990. Each class has a verbal designation of abnormality level. If data are compared with normal, it is allowed to use just verbal designation for normal.

Evaluative criteria can be used if the air temperature deviation was calculated from long-term average (note that it must be clearly indicated for which period the long-term average was calculated; e.g. 1951-1980). In this case, the deviation is calcu-

T

The index classes [\%] for evaluating the precipitation abnormality of months, half years and years in the Slovak Republic, Zone I.

\begin{tabular}{|c|c|c|c|c|c|c|c|}
\hline \multirow{4}{*}{$\begin{array}{l}\text { Month / } \\
\text { period }\end{array}$} & \multicolumn{7}{|c|}{ Normal } \\
\hline & 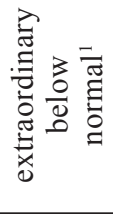 & 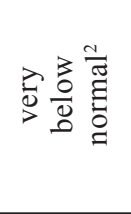 & $\begin{array}{l}3 \\
\frac{m}{\tilde{Z}} \\
0 \\
0 \\
0\end{array}$ & $\begin{array}{l}\frac{ \pm}{\tilde{J}} \\
\stackrel{\Xi}{\Xi} \\
\stackrel{0}{\Xi}\end{array}$ & 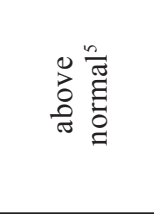 & 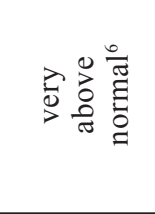 & 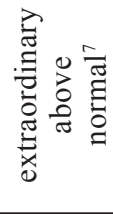 \\
\hline & \multicolumn{7}{|c|}{ Long-term average } \\
\hline & 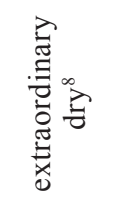 & $\begin{array}{l}\vec{\partial} \\
\vec{\theta} \\
\overrightarrow{0} \\
>\end{array}$ & $\stackrel{\circ}{\gtrless}$ & 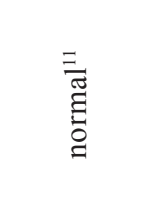 & $\frac{7}{2}$ & $\begin{array}{l}\frac{9}{0} \\
0 \\
3 \\
2 \\
0 \\
>0\end{array}$ & 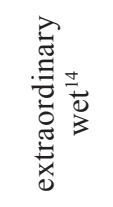 \\
\hline I. & $<20$ & 20 to 39 & 40 to 59 & 60 to 130 & 131 to 170 & 171 to 230 & $>230$ \\
\hline II. & $<20$ & 20 to 39 & 40 to 59 & 60 to 130 & 131 to 180 & 181 to 240 & $>240$ \\
\hline III. & $<20$ & 20 to 39 & 40 to 59 & 60 to 130 & 131 to 180 & 181 to 250 & $>250$ \\
\hline IV. & $<30$ & 30 to 49 & 50 to 69 & 70 to 120 & 121 to 160 & 161 to 200 & $>200$ \\
\hline $\mathrm{V}$. & $<30$ & 30 to 49 & 50 to 69 & 70 to 120 & 121 to 160 & 161 to 210 & $>210$ \\
\hline VI. & $<30$ & 30 to 49 & 50 to 69 & 70 to 130 & 131 to 160 & 161 to 210 & $>210$ \\
\hline VII. & $<20$ & 20 to 49 & 50 to 69 & 70 to 130 & 131 to 170 & 171 to 220 & $>220$ \\
\hline VIII. & $<30$ & 30 to 49 & 50 to 69 & 70 to 120 & 121 to 160 & 161 to 210 & $>210$ \\
\hline IX. & $<20$ & 20 to 39 & 40 to 59 & 60 to 130 & 131 to 170 & 171 to 230 & $>230$ \\
\hline$X$ & $<0$ & 0 to 29 & 30 to 59 & 60 to 130 & 131 to 170 & 171 to 230 & $>230$ \\
\hline XI. & $<10$ & 10 to 29 & 30 to 59 & 60 to 130 & 131 to 180 & 181 to 240 & $>240$ \\
\hline XII. & $<20$ & 20 to 39 & 40 to 69 & 70 to 130 & 131 to 170 & 171 to 220 & $>220$ \\
\hline I.-XII. & $<60$ & 60 to 79 & 80 to 89 & 90 to 110 & 111 to 120 & 121 to 140 & $>140$ \\
\hline IV.-IX. & $<60$ & 60 to 69 & 70 to 79 & 80 to 120 & 121 to 130 & 131 to 150 & $>150$ \\
\hline X.-III. & $<50$ & 50 to 69 & 70 to 79 & 80 to 120 & 121 to 130 & 131 to 160 & $>160$ \\
\hline
\end{tabular}

IV.-IX. - warm half-year; X.-III. - cold half-year;

Note that in Slovak language we never use term 'extrémne' and classes translate as: 'mimoriadne podnormálny, ${ }^{2}$ silne podnormálny, ${ }^{3}$ podnormálny, ${ }^{4}$ normálny, ${ }^{5}$ nadnormálny, ${ }^{6}$ silne nadnormálny, ${ }^{7}$ mimoriadne nadnormálny, ${ }^{8}$ mimoriadne suchý, ${ }^{9}$ vel'mi suchý, ${ }^{10}$ suchý, ${ }^{11}$ normálny, ${ }^{12} \mathrm{vlhký},{ }^{13} \mathrm{vel} m i$ vlhký, ${ }^{14}$ mimoriadne vlhký 
lated as a difference between the valuated average air temperature and long-term average for identical period (month, year), valid for the evaluated site of Slovak Republic. The index is calculated as:

$$
T-l(T)
$$

where:

$T$ denotes the longer period's average air temperature, $l(T)$ is long-term average for the same period and valid for the evaluated site of Slovak Republic (Lapin et al. 1987).
If data are compared with long-term average, it is allowed to use verbal designation for normal and long-term average as well.

\section{Precipitation}

Drought is considered as one of the biggest natural disasters that affects the society more than others. Drought as well as wet can be computed by using quantitative indices in the time scale. Indices measure how much precipitation for a given period of time has deviated from historically established

$\mathrm{T}$ a $\mathrm{b} 1$ e 3

The index classes [\%] for evaluating the precipitation abnormality of months, half years and years in the Slovak Republic, Zone II.

\begin{tabular}{|c|c|c|c|c|c|c|c|}
\hline \multirow{4}{*}{$\begin{array}{l}\text { Month / } \\
\text { period }\end{array}$} & \multicolumn{7}{|c|}{ Normal } \\
\hline & 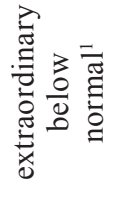 & 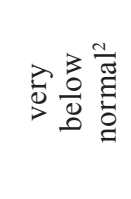 & 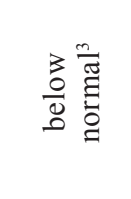 & 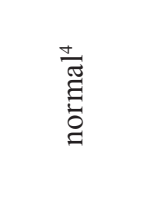 & 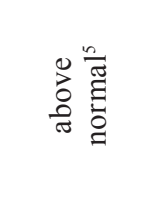 & 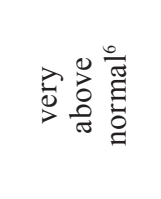 & 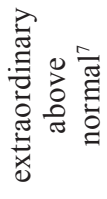 \\
\hline & \multicolumn{7}{|c|}{ Long-term average } \\
\hline & 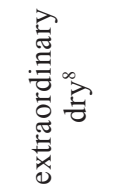 & $\begin{array}{l}2 \\
\vec{\theta} \\
2 \\
\overrightarrow{0} \\
>\end{array}$ & 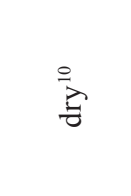 & 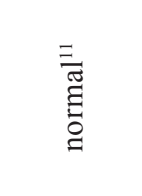 & $\frac{2}{0}$ & $\begin{array}{l}\frac{m}{0} \\
0 \\
3 \\
2 \\
0 \\
0\end{array}$ & 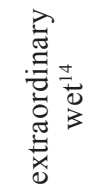 \\
\hline I. & $<10$ & 10 to 29 & 30 to 49 & 50 to 140 & 141 to 190 & 191 to 280 & $>280$ \\
\hline II. & $<0$ & 0 to 29 & 30 to 59 & 60 to 140 & 141 to 190 & 191 to 260 & $>260$ \\
\hline III. & $<10$ & 10 to 29 & 30 to 49 & 50 to 130 & 131 to 190 & 191 to 280 & $>280$ \\
\hline IV. & $<10$ & 10 to 39 & 40 to 59 & 60 to 130 & 131 to 170 & 171 to 210 & $>210$ \\
\hline V. & $<10$ & 10 to 39 & 40 to 59 & 60 to 130 & 131 to 160 & 161 to 220 & $>220$ \\
\hline VI. & $<10$ & 10 to 39 & 40 to 69 & 70 to 140 & 141 to 180 & 181 to 250 & $>250$ \\
\hline VII. & $<10$ & 10 to 39 & 40 to 59 & 60 to 140 & 141 to 180 & 181 to 260 & $>260$ \\
\hline VIII. & $<20$ & 20 to 39 & 40 to 59 & 60 to 130 & 131 to 170 & 171 to 250 & $>250$ \\
\hline IX. & $<0$ & 0 to 19 & 20 to 49 & 50 to 130 & 131 to 180 & 181 to 260 & $>260$ \\
\hline $\mathrm{X}$. & $<0$ & 0 to 19 & 20 to 49 & 50 to 130 & 131 to 190 & 191 to 280 & $>280$ \\
\hline XI. & $<0$ & 0 to 29 & 30 to 59 & 60 to 140 & 141 to 180 & 181 to 250 & $>250$ \\
\hline XII. & $<10$ & 10 to 39 & 40 to 69 & 70 to 140 & 141 to 180 & 181 to 230 & $>230$ \\
\hline I.-XII. & $<60$ & 60 to 79 & 80 to 89 & 90 to 110 & 111 to 120 & 121 to 140 & $>140$ \\
\hline IV.-IX. & $<60$ & 60 to 69 & 70 to 79 & 80 to 120 & 121 to 130 & 131 to 150 & $>150$ \\
\hline X.-III. & $<50$ & 50 to 69 & 70 to 79 & 80 to 120 & 121 to 130 & 131 to 160 & $>160$ \\
\hline
\end{tabular}

IV.-IX. - warm half-year; X.-III. - cold half-year;

Note that in Slovak language we never use term 'extrémne' and classes translate as: ${ }^{1}$ mimoriadne podnormálny, ${ }^{2}$ silne podnormálny, ${ }^{3}$ podnormálny, ${ }^{4}$ normálny, ${ }^{5}$ nadnormálny, ${ }^{6}$ silne nadnormálny, ${ }^{7}$ mimoriadne nadnormálny, ${ }^{8}$ mimoriadne suchý, ${ }^{9}$ vel'mi suchý, ${ }^{10}$ suchý, ${ }^{11}$ normálny, ${ }^{12}$ vlhký, ${ }^{13}$ vel'mi vlhký, ${ }^{14}$ mimoriadne vlhký 
norms. Any forms of drought and wet are related to some antecedent and relative precipitation amounts for the previous period. The simplest expression of difference from the normal could be defined as a drought index, the so called precipitation index percent of normal:

$$
P / n(P) \times 100
$$

where:

$P$ denotes the longer period's sum of precipitation, $n(P)$ is precipitation normal for the same period and valid for the evaluated site of Slovak Republic (Lapin et al. 1987).

Table 2 and 3 shows the precipitation index thresholds elaborated following the methodology of Slovak Hydrometeorological Institute (Lapin et al. 1987) valid for the territory of Slovakia in relation to the normal 1961-1990.

In case of annual and half-year precipitation, the evaluation index thresholds are the same in both tables and are valid for all sites in Slovakia.

To rate the monthly precipitation abnormality evaluation, it is necessary to see and use the Figure 1. Evaluated site (site belongs to evaluated precipitation data) must be integrated into the zone in relation to the evaluated period of year using the map presented in Figure 1. The territory of Slovakia is divided into two zones (Zone I and Zone II) for each period of the year, and the year is divided into four periods (three months in period). There are two periods of the year (February to April and August to October) in the map with the same zoning. Table 2 is valid for the sites integrated to Zone I and Table 3 is valid for sites integrated to Zone II.

Verbal designation of abnormality levels is presented in Table 2 and 3 together with the mentioned precipitation index thresholds. If data are compared with normal, it is allowed to use just verbal designation for normal.

Evaluative criteria can be used if precipitation index is calculated from long-term sum (note that the period of long-term average calculation must be clearly indicated; e.g., 1951-1980). In this case, the precipitation index percent of normal is calculated as:

$$
P / l(P) \times 100
$$

where:

$P$ denotes the longer period's sum of precipitation, $l(P)$ is the precipitation long-term average for the same period and valid for the evaluated site of Slovak Republic (Lapin et al. 1987).

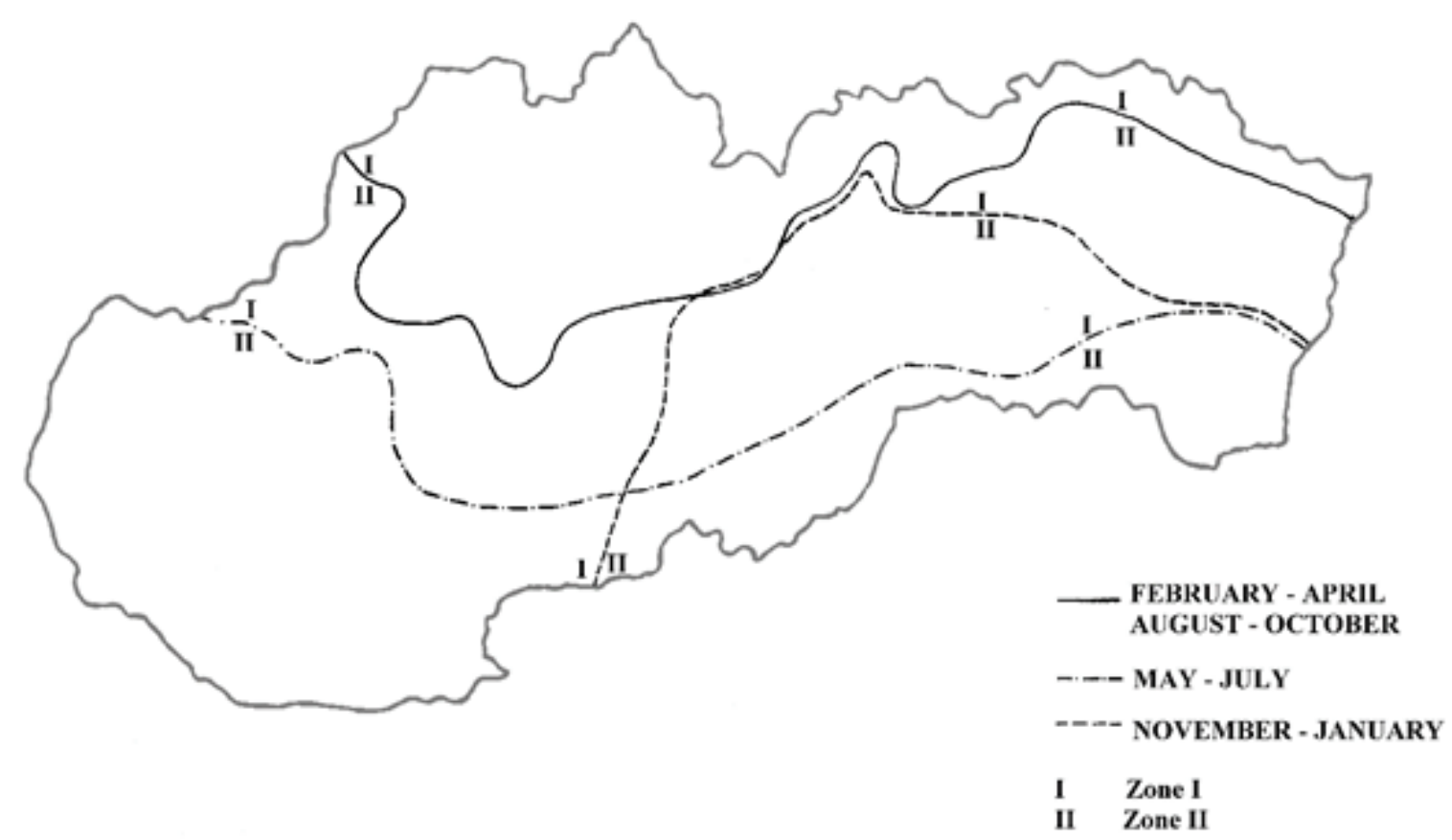

Figure 1. Division of territory of Slovak Republic into Zone Land II based on the amount of precipitation over a period of three months (Lapin et al. 1987) 
Next step in the procedure is the same as for comparing with normal, in case of monthly precipitation evaluation, the site must be integrated in to one of two zones (see above). If data are compared with long-term sum, it is allowed to use verbal designation for normal and for long-term sum as well.

\section{CONCLUSIONS}

Air temperature and precipitation data are more useful when they are compared with normal values or long-term values. Relationship between observed and baseline conditions is simply expressed by climate index. The purpose of the index is to reduce complex conditions to a single number that retains some physical meaning and can be used to monitor a particular process. Climate indices are widely used to characterise features of the climate for climate prediction and to detect climate change. They may apply to individual climatological stations or describe some aspect of climate of the area. Climate indices must be calculated using the relevant data of normal or long-term averages and relevant evaluative criteria. The criteria presented in this work are fully applicable for weather evaluation in the Slovak Republic.

\section{REFERENCES}

WMO, 2007: The Role of Climatological Normals in a Changing Climate. Geneva : WMO. WCDMP-No. 61, WMO TD/No.1377. Available at http://www.wmo.int/pages/prog/ wcp/wcdmp/documents/WCDMPNo61.pdf. (accessed February 16, 2017)

WMO, 1989. Calculationofmonthly and annual 30-year standardnormal. Geneva: WMO. WCDP-No.10, WMO-TD/ No.341, 12 pp. Available at http://www.inmet.gov.br/html/ clima/OMM_WCDP_N10.pdf. (accessed February 16, 2017)

MIKULOVÁ, K. - ŠŤASTNÝ, P. - BOCHNÍČEK, O. - BORSÁNYI, P. - ČEPČEKOVÁ, E. - ONDRUŠKA, P. 2015a. National Climate Program of The Slovak Republic : Climatological normals in the period 1961-1990 in Slovakia : Part I-Climatological normals of airtemperature in Slovakia in the period 1961-1990: Ministry of Environment of the Slovak Republic, Slovak Hydrometeorological Institute, $135 \mathrm{pp}$. ISBN 978-80-88907-92-3

MIKULOVÁ, K. - FAŚKO, P. - ŠŤASTNÝ, P. 2015b. National Climate Program of The Slovak Republic : Climatological normals in the period 1961-1990 in Slovakia : Part II Climatological normals of precipitation in Slovakia in the period 19611990 : Ministry of Environment of the Slovak Republic, Slovak Hydrometeorological Institute, 640 pp. ISBN 978-80-88907-93-0

LAPIN, M. - FAŠKO, P. 1987. Climatological normal. Methodical regulation. Bratislava : Slovak Hydrometeorological Institute, $22 \mathrm{pp}$.

Received: February 2, 2017 